\title{
Analysis of Public Policy on the Shopping Budget and Regional Income of East Java Province (Study of Rpjmd of East Java Province 2014-2019 and Its Impact on Regional Budget)
}

\author{
Bagus Djulig Wijono \\ Student of Doctor Study Program of Administration Sciences - FISIP, Universitas 17 Agustus 1945 \\ Surabaya, Jl. Semolowaru No. 45 Surabaya, Jawa Timur, Indonesia
}

\begin{abstract}
The ability of the Regional Government in planning the budget is something that is very influential in order to realize the goals set through the Medium Term Development Plan. The change in the paradigm of the government system from centralistic to decentralized (regional autonomy) has the consequence of a change in the development planning paradigm from a sectoral development approach to a regional (regional) approach.This study uses qualitative methods, to see whether the budget planning implemented by the East Java Provincial Government is in accordance with public policy, and sees its potential, taking into account the development of the 2014-2019 Medium Term Development Plan.The results achieved in this study are mostly the budget planning process that is applied in accordance with public policy, which starts from the bottom, although the results obtained are still not fully in accordance with the target. And this is evident that East Java is the province that first applied ebudgeting, so that budget management can be more transparent and accountable.
\end{abstract}

Keywords: Analysis of public policy, Regional Revenue and Expenditure Budget

DOI: 10.7176/PPAR/9-4-04

Publication date: April $30^{\text {th }} 2019$

\section{Introduction}

In policy, state power meets with sovereignty which, in the norms of democracy, is held by the people or citizens. Because in the nation-state regime which is currently dominant, only the state has the legitimacy to make a public policy. In the context of democracy, the most basic question about a policy is; "How far is the government policy 'linked' to the citizens' public will?

The state is a legitimate holder of power. Because public policy is basically a state policy, public policy is often interpreted as an action taken by the power holders to ensure that the goals that have been formulated and agreed upon by the public can be achieved. Therefore, the issue of public policy can be interpreted as a matter of the use of power.

Likewise with the policy for determining the 2014-2019 Regional Medium-Term Development Plan as one of the decisions of the Provincial Government Decision making is a processchoose an alternative way of acting with an efficient method according to the situation (Salusu, 1996: 47). This process is to find and solve organizational problems. This statement confirms that making decisions requires a series of actions, requiring several steps. It can be that these steps are contained in someone's mind which at the same time invites him to think systematically. In the world of management the process or series of actions are more visible in discussion activities.

Paradigm changes and approaches in national development planning launched through the stipulation of legislative policies (Law Number 25 of 2004 concerning National Development Planning Systems, Law Number 32 of 2004 concerning Regional Government, and Government Regulation Number 8 of 2008 concerning In stages, the Procedure for Preparation, Control and Evaluation of the Implementation of Regional Development Plans) in principle is an effort to reorganize and prioritize the preparation of national and regional development plans in a systematic, directed, integrated, comprehensive, and responsive manner to changes, as well as ensuring linkages and consistency between planning, implementation, and control and evaluation of the implementation of the development plan.

Efforts to achieve success in regional development require strategic planning formulated in the Regional Medium-Term Development Plan (RPJMD). The inauguration of the Regional Head and Deputy Regional Head of East Java Province from the direct election results, on February 12, 2009, became the initial milestone in the completion of the 2009-2014 RPJMD in accordance with Article 19 paragraph (3) of Law Number 25 Year 2004, RPJMD stipulated with Regional Head Regulation no later than three months after the regional head is appointed.

Regarding efforts to realize regional development planning that is systematic, directed, integrated, comprehensive, and responsive to change, the East Java Provincial Government has stipulated Regional Regulation No. 1 of 2009 concerning the Regional Long Term Development Plan (RPJPD) 2005-2025 and Regional Regulations Number 5 of 2012 concerning the Regional Spatial Planning (RTRW) of East Java 
Province 2011-2031 and various other related planning documents. The regional planning document serves as a guideline and foundation for the preparation of various regional development planning documents, both fiveyear and annual.

The RPJMD of East Java Province for 2014-2019 is a development planning document for East Java Province for a period of 5 (five) years which is prepared in accordance with provincial authority and its preparation is guided by the 2005 - 2025East Java Provincial RPJPD and RTRW East Java Province 2011-2031 and pay attention to the 2010-2014 RPJMN. The 2014-2019 East Java RPJMD was then referred to by all SKPDs in East Java Province according to their Main Tasks and Functions and it was hoped that in general it would be able to become a guideline for all communities and development stakeholders in the implementation of regional development in East Java Province.

The RPJMD document will then be elaborated into the Regional Development Work Plan (RKPD). The RKPD is an annual plan that includes a draft regional economic framework, regional development priorities, work plans and funding. As mandated by Article 25 paragraph (2) of Law Number 25 of 2004 stated that the RKPD is a guideline for drafting the Regional Budget (RAPBD). Therefore the RPJMD of East Java Province can be said to be the estuary of the entire five-year development in the East Java region that needs to be referred by all development stakeholders in East Java in realizing the expected goals and objectives. Therefore the determination of the RPJMD will greatly determine the amount of the budget that must be provided by the Provincial Government.

The preparation of the RKP is carried out using a Thematic, Holistic, Integrative, and Spatial approach, as well as a budget policy based on the money follows program by ensuring that only truly useful programs are allocated and not merely because of the duties of the relevant Ministries / Institutions. This implies that the achievement of national development priorities requires the coordination of all stakeholders, through the integration of national priority / program priorities / activities implemented in a regional basis.

Regional financing is a regional financial transaction intended to cover the difference between regional income and regional expenditure. If regional income is smaller than regional expenditure, financial transactions occur that are deficit, and must be covered with regional revenues. Conversely, if regional income is greater than regional expenditure, then financial transactions are surplus, and must be used for regional expenditure. Therefore, regional financing consists of regional revenues and regional expenditures.

Fitzgerald and Pettigrew, as quoted by Yeremias T Keban, said that the New Public Management had undergone a change of orientation. The stages of change in the orientation of the New Public Management include:

1. The efficiency drive, which prioritizes efficiency values in performance measurement.

2. Downsizing and decentralization, which prioritizes simplification of structures, enriches functions and delegates authority to smaller units in order to function quickly and precisely.

3. In search of excellence, which prioritizes optimal performance by utilizing science and technology.

4. Public service orientation, emphasizes the quality, mission and values to be achieved by public organizations, giving greater attention to the aspirations, needs, and participation of "users" and citizens, giving higher authority to elected officials of the community, including their representatives, emphasizes social learning in the delivery of public services, and emphasizes continuous performance evaluation, community participation and accountability.

In the new paradigm of state administration, further explained by Warsito Utomo that "all processes, systems, procedures, hierarchies or lawfull states are no longer the main reference even though it still needs to be known and is a skill. But results, teamwork, flexibility must be prioritized, caused by pressure, influence, the existence of differentiated public demand ".

Policy analysis is an activity of creating knowledge about and in the policy making process. In creating knowledge about policy-making processes, policy analysts examine the causes, effects, and performance of public policies and programs.

Dror in Wahab (2012: 40) defines policy analysis as:

"An approach and methodology for design and identification of useful alternatives to complex policy issues" (an approach and methodology for designing and finding desired alternatives regarding a number of complex issues). Whereas Kent in Wahab (2012: 41) defines policy analysis,

"That is kind of systematic, analytical, scholarly, creative learning, which is primary motivation is to produce well-supported recommendations for action dealing with concrete problems" (a type of systematic, disciplined, analytical, intelligent, and creative study conducted with the intention of producing recommendations reliable form of actions to solve concrete problems).

\section{Regional Medium Term Development Plan (RPJMD)}

This East Java Province RPJMD 2009-2014 document basically describes a strategic plan that is closely related to the process of determining where the East Java region will be directed towards its development, and what will 
be achieved in the next five years, how to achieve it, and what strategic steps need to be taken so that the goal is achieved - according to the vision, mission and program of the elected regional head.

Strategic planning ensures that regional resources and funds are directed at addressing priority issues and problems, while providing a basis for measuring the extent to which progress is being made in achieving objectives, and providing a mechanism to inform changes if needed. Except that, through strategic planning contained in the RPJMD, the direction of regional development in East Java can be better understood by the public and private business people, so as to give birth to a sense of belonging and responsibility for a mutually agreed strategic plan.

The Regional Medium Term Development Plan will be further elaborated in the next Regional Development Work Plan (RKPD) which is valid for one fiscal year, which contains the draft regional economic framework, regional development priorities, work plans and funding.

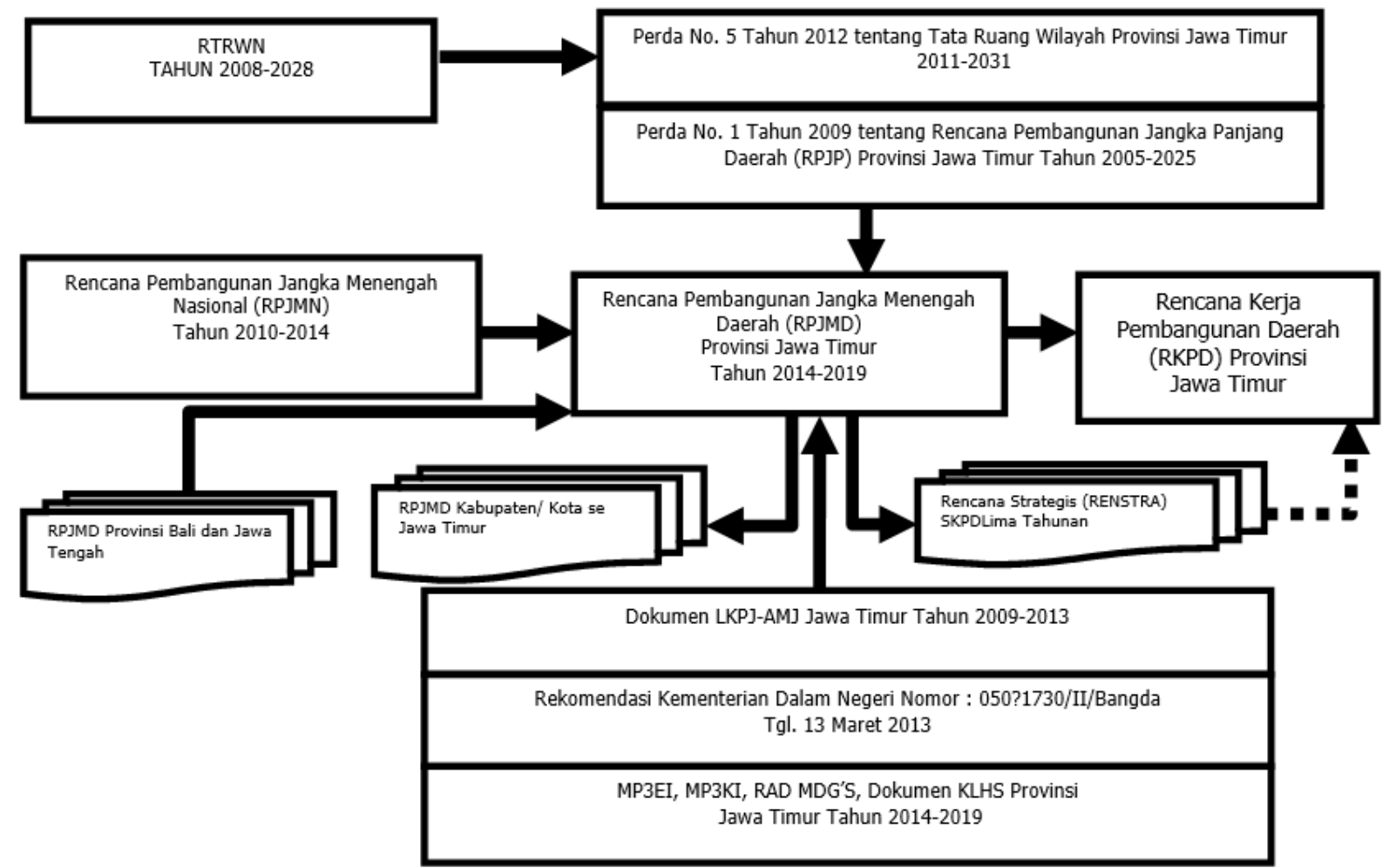

Picture 1

Relationship between RPJMD and Documents

Other Regional Development Planning

In preparing the RPJMD, East Java Province applies the framework as in the picture below: 


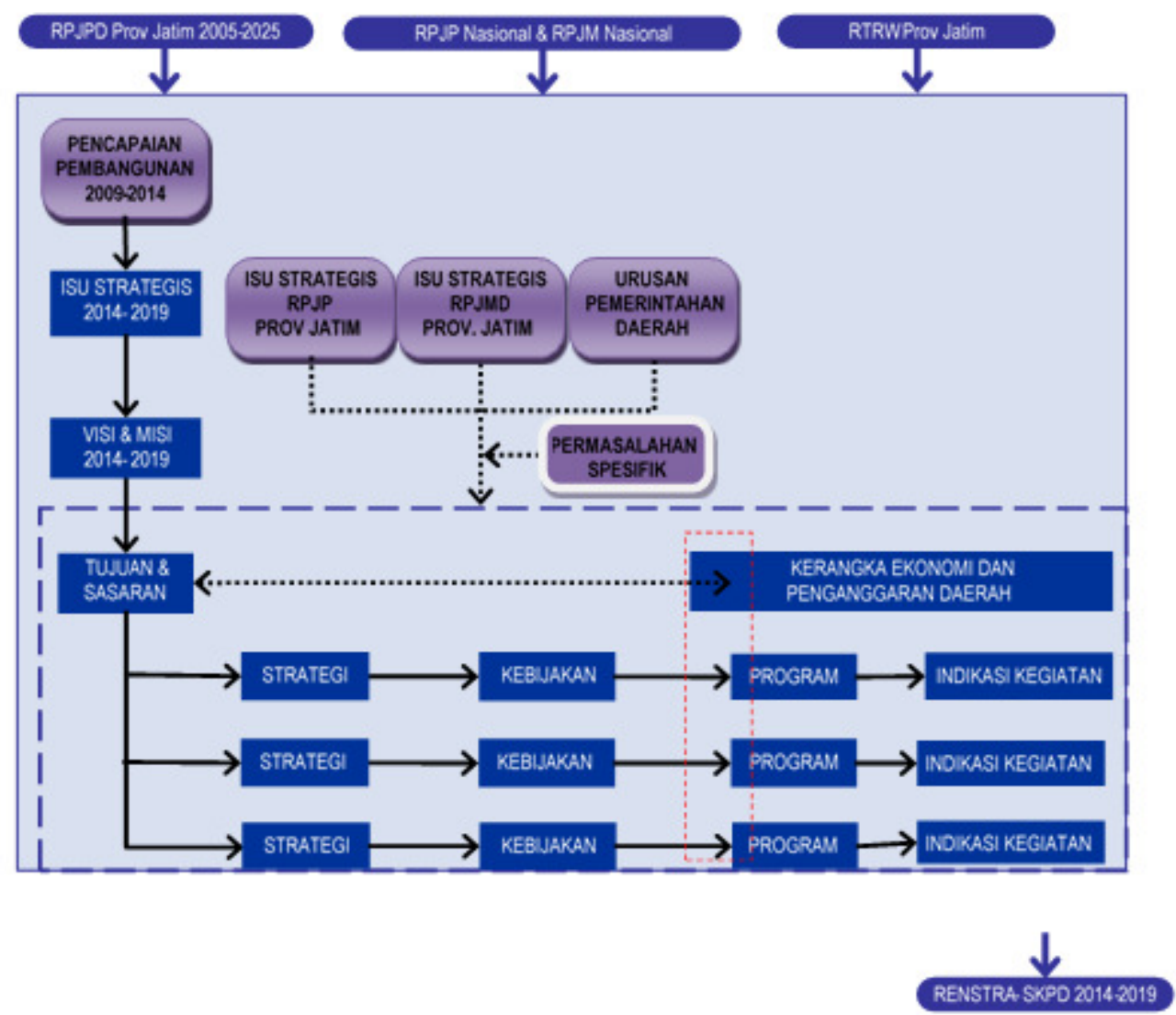

Figure 2

Framework of RPJMD for East Java Province 2014-2019

\section{Research Methods}

\section{Philosophical foundation and research approach}

In social research, a philosophical foundation is needed to accurately describe the phenomena to be examined. Then the conceptual definition used as a reference in this study are:

Public policy analysis

Policy analysis is an applied social science discipline that uses a variety of research methods and arguments to produce and transfer information that is relevant to policy, so that it can be utilized at the political level in ordersolve policy problems. One of the essence of the presence of public policy (public policy) is to solve problems that develop in society correctly.

Regional Revenue and Expenditure Budget (APBD)

It is the budget of the East Java Provincial Government which was decided through the Provincial Regional Representative Council and poured into the East Java Provincial Regulation every year.

Regional Medium Term Development Plan (RPJMD)

As a regional planning document that contains the vision and mission and development program for 5 (five) years, the plan must be guided by the RPJMD which has a duration of 20 (twenty) years and also serves as a guideline for annual development planning in the RKPD document. In operationalizing the achievement of the vision, mission, goals and objectives in the RPJMD, all SKPD / OPD prepare a 5 (five) year SKPD / OPD Strategic Plan. The success of the SKPD / OPD Strategic Plan is very much determined by the implementation of the SKPD / OPD Renja as the annual planning documents of each SKPD / OPD.

Budgeting system

The budget is a plan that is systematically arranged in the form of numbers and expressed in a monetary unit which covers all company activities for a certain period (period) in the future. Because the plan drawn up is expressed in the form of a monetary unit, the budget is often referred to as a financial plan. In the budget, activity units and units of money occupy important positions in the sense that all activities will be quantified in units of money, so that the achievement of efficiency and effectiveness can be measured.

Method of collecting data 
In this study the procedure for collecting data was carried out through several steps:

1. Primary Data

Data directly obtained from the first data source at the research location or research object.

\section{Secondary Data}

Data obtained from the second source or secondary data source that we need. Online data is a category of secondary data (Bungin, 2004: 121). Secondary data in this study were obtained from interviews with BPKAD East Java Province and existing textbooks and from scientific writing related to this research.

\section{Data analysis technique}

The data were analyzed descriptively qualitatively, the collected data was then reduced in the form of findings that were relevant to the focus of the study, then presented in narrative form, so that the data would be presented descriptively, factually and systematically.

The next process is drawing conclusions, analyzing this data is a logical description, where both qualitative and quantitative data are presented complementary.

By still adhering to the formulation of the problem and the focus of research, the basis of data analysis in this study will be to use comparative studies by comparing the preparation of the previous budget with the preparation of the budget to be made.

\section{Finding data and analysis}

1. Budgeting Mechanism

The budget is a guideline for actions implemented by the government including plans, revenues, expenditures, transfers, and financing which are measured in rupiah units which are arranged according to certain classifications systematically for one period. Government budget is a formal document resulting from the agreement between the executive and the legislature about expenditure and income which is expected to cover the expenditure or financing needs. The budget coordinates government expenditure activities and provides the basis for efforts to obtain income and financing for the budget period, that is the annual period.

In another meaning it can be said that the budget as a financial plan states:

1. Organizational plans to serve other people or activities which can develop organizational capacity in service.

2. Estimated amount of costs that must be spent in realizing the plan.

3. Estimates of which sources will generate income and how much income will be made.

The public budget is a document that describes the financial condition of an organization which includes information about income, expenditure, and activities (Nordiawan, 2006: 48).

The public budget is a financial plan that states:

1. What are the costs for the plan made (expenses / costs), and

2. How much and how to get money to fund the plan (income).

One of the mechanisms in budgeting is through the Musrenbang that is implemented starting from the village / kelurahan to the district, provincial and national levels. So that it is expected that the development plan can be started from the bottom according to the needs of the region, but in reality the Musrenbang is carried out more leads from above adjusting to the capabilities of the available provincial budget and the vision and mission of the government.

These are suitable with the results of the interview with Dr.AhmadSukardi which explained that there were separate difficulties in being able to absorb all the aspirations of the district / city, given the limited sources of funds available. So that the absorption of regional aspirations is adjusted to the Governor's policy by determining development priorities that must be carried out every year, where for 2019 the development priorities in East Java are directed to: Human development in East Java as a lever of inclusion growth, which consists of :

a. Improving the quality of human resources through improving the quality of education, health, employment and poverty reduction

b. Equitable development between regions through the development of economic infrastructure and information technology to grow growth centers

c. Increased agro added value for agro and maritime through industry and utilization of tourism acceleration

d. Increased food and energy security and water resources governance, conservation of natural resources and a sustainable environment

e. Increased peace and order and the success of the election

On the other hand, the Head of the Regional Development Planning Agency (Bappeda) further emphasizes that in developing a development program, it must first be known about the development of the development results that have been carried out, as well as 


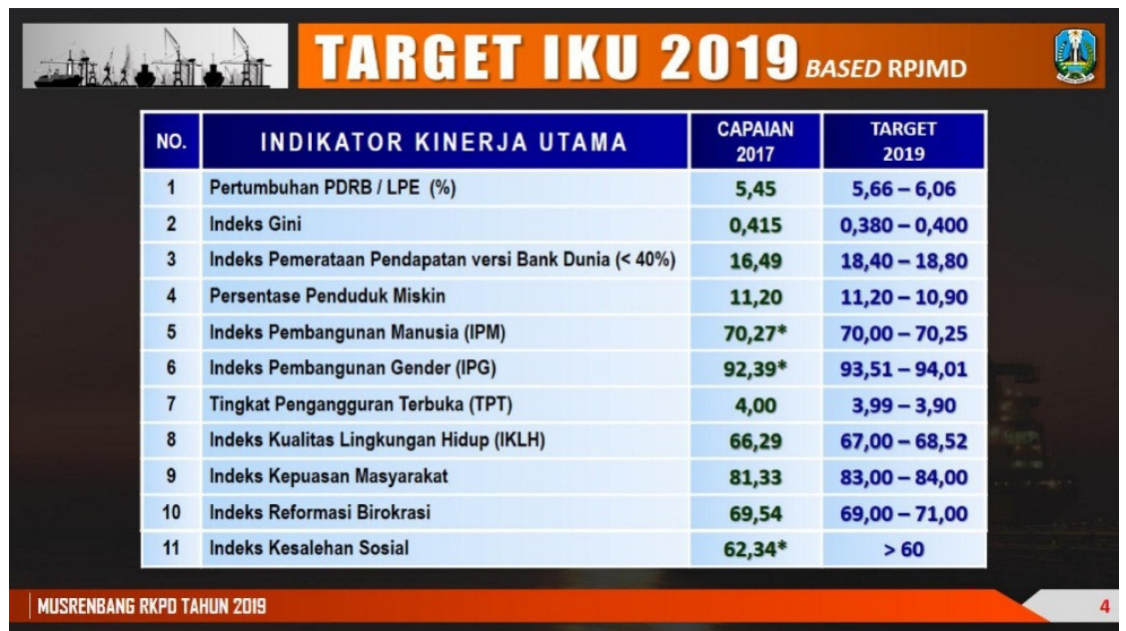

Picture 3

IKU Target

Scheme 1

The New Financing in Forward

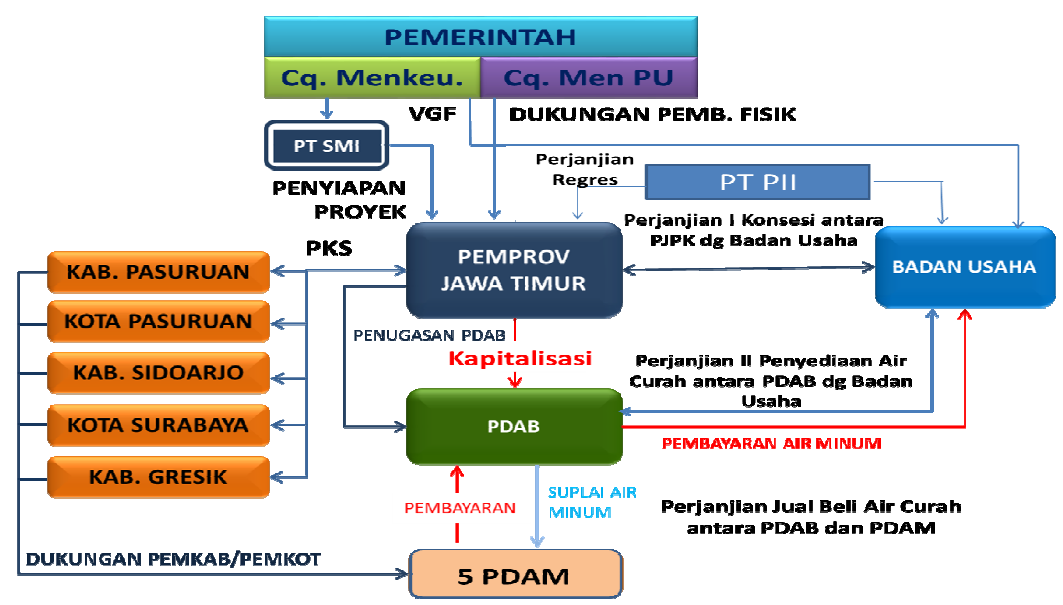

2. Determination of priority scale

Determining the priority scale of development will always be associated with the availability of budgets from the Remaining Income of the Year, Regional Original Revenue (PAD) including taxes, fees, regional operating profits, General Allocation Funds (DAU), Special Allocation Funds (DAK), Higher Income from Government Giviing, therefore, determining the priority scale is also based on the results of the musrenbang, based on the results of the data and the Regional Medium Term Development Plan (RPJMD), with the target of the Main Performance Index (IKU) as follows:

Tabel1 : The Main Performance Index Target (IKU)

\begin{tabular}{|l|l|c|c|c|}
\hline \multirow{2}{*}{ NO } & \multicolumn{1}{|c|}{ REGIONAL MAIN PERFORMANCE } & \multicolumn{3}{|c|}{ TARGET } \\
\cline { 3 - 5 } & \multicolumn{1}{|c|}{ INDICATORS } & 2017 & 2018 & 2019 \\
\hline 1 & Growth of PDRB/LPE (\%) & $5,56-5,86$ & $5,61-5,96$ & $5,66-6,06$ \\
\hline 2 & Gini Index & $0,390-0,400$ & $0,385-0,400$ & $0,380-0,400$ \\
\hline 3 & Income Equity Index World Bank Version $(<40 \%)$ & $18,00-18,20$ & $18,00-18,40$ & $18,40-18,60$ \\
\hline 4 & Percentage of poor people & $11,80-11,50$ & $11,50-11,20$ & $11,20-10,90$ \\
\hline 5 & Human Development Index & $69,50-69,75$ & $69,75-70,00$ & $70,00-70,25$ \\
\hline 6 & Gender Development Index & $92,39-92,90$ & $92,91-93,50$ & $93,51-94,01$ \\
\hline 7 & Open unemployment rate & $4,17-4,08$ & $4,08-3,99$ & $3,99-3,90$ \\
\hline 8 & Environmental quality index & $63,98-65,49$ & $65,49-67,00$ & $67,00-68,52$ \\
\hline 9 & Community satisfaction index & $81,00-82,00$ & $82,00-83,00$ & $83,00-84,00$ \\
\hline 10 & Index of bureaucratic reform & $65,00-67,00$ & $67,00-69,00$ & $69,00-71,00$ \\
\hline 11 & Index of social piety & $>60$ & $>60$ & $>60$ \\
\hline
\end{tabular}

Source :Governor's explanation at 2018 Musrenbang 
3. Coordination of the Executive budget team

In managing regional finance, the regional secretary holds two functional positions, as KPKD (Regional Financial Management Coordinator) and leads the TAPD (Regional Government Budget Team). The position of regional secretary as KPKD is the delegation of part or all of the power of the regional head as the holder of regional financial management authority stipulated by the Decree of the Regional Head, while the position of regional secretary as chairman of the TAPD is mandated by legislation (Government Regulation Number 58 of 2005 Management Regional Finance and Permendagri Number 13 of 2006 concerning Guidelines for Regional Financial Management as last amended by Permendagri Number 21 of 2011).

The task of regional secretary as KPKD, as stipulated in article 6 paragraph (1) Government Regulation Number 58 of 2005 Management of Regional Finance, and article 6 paragraph (2) Permendagri Number 13 of 2006 concerning Guidelines for Regional Financial Management as last amended by Permendagri Number 21 of 2011, "The Regional Financial Management Coordinator (Regional Secretary) as referred to in Article 5 paragraph (4) has a coordination task in the fields of :

a. Preparation and implementation of APBD management policies;

b. Preparation and implementation of regional goods management policies;

c. Preparation of the draft APBD and draft changes to the APBD;

d. Preparation of the Regional Budget Draft Regional Regulation, changes in the Regional Budget, and accountability for the implementation of the APBD;

e. Tasks of regional planner officials, PPKD, and regional financial supervisor officials; and

f. Preparation of regional financial reports in the context of accountability for the implementation of the APBD

For East Java Province the Duties of the Regional Government Budget Team in accordance with the Governor's Decree have the following tasks:

a. Compile the Draft Regional Regulation of East Java Province on the APBD, the amendment of APBD and Accountability for APBD Implementation;

b. Drafting the Draft Regulation of the East Java Governor concerning the Elaboration of the Regional Budget, Amendments to the Regional Budget and the Accountability of the Regional Budget Implementation;

c. Compile regional financial reports in the framework of accountability for the implementation of the APBD;

d. Planning the establishment of regional revenue targets as the basis for drafting the APBDand the APBDChanges;

e. Determine the program / activity priority scale and the amount of the budget allocation while still referring to the APBD General Policy (KUA) and the Temporary Budget Ceiling Priority (PPAS);

f. Compile the fnancial note on the APBD draft, APBDamendment, and accountability for APBD implementation;

g. Compiling Executive Answers on the General View of the Fractions, Reports of Commissions and the Budget Agency's Opinion Report on the Draft Regional Regulation of East Java Province on the APBD, APBD amendments, and the accountability of APBD Implementation;

h. Form a Secretariat as needed;

i. $\quad$ Form a Technical Document Verification Team

j. $\quad$ Budget Implementation (DPA) and Budget Change Implementation Document (DPPA) as needed; report the results of the implementation of their duties to the Governor of East Java.

In preparing budget planning by adjusting the existing vision and mission, according to the informant who was successfully interviewed, explained that the budget or income of the East Java Provincial Government came from:

1. Local revenue:

2. Balancing funds:

3. Other legitimate regional income:

Of the three existing posts, it can be seen that the Regency / city and East Java Provincial Government revenues for the last 3 years are as shown in the graph below 
Graph. 1 Original Revenue from Regency / City Region

100.00

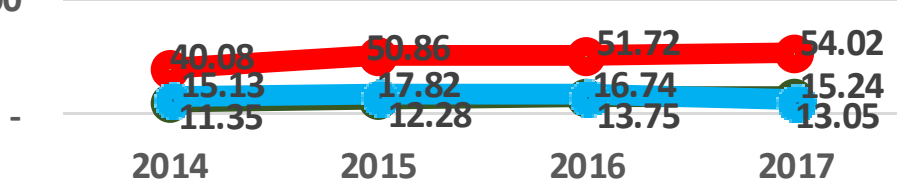

Locally Generated Revenue Balance Fund $\quad$ Other Legitimate Regional Income

Graph. 2 The Revenue of East Java Province Year 2009-2017

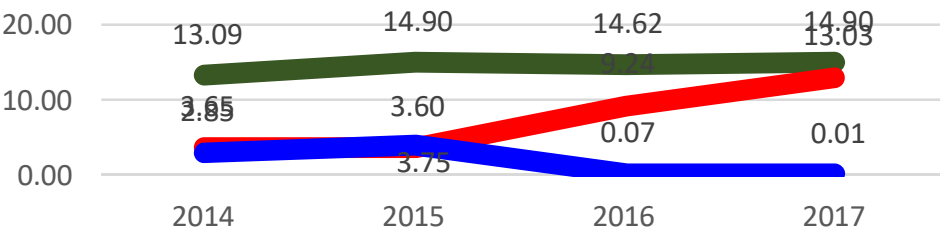

Information :

- $\quad$ Provincial PAD JATIM is relatively more independent

- $\quad$ During the last 3 years PAD of Jatimprovince relatively stagnan(impact of economic slowdown)

- Impact of assignment of affairs (P3D) such as BOS, Teacher Salary, High School Vocational School (DAU)

a. Coordination with the legislative budget team

The legislature is responsible for enforcing the budget or approving it formally at the formal legal level (Norton and Elson 2002) DPRD has a role to propose changes to the income and expenditure side of the RAPBD proposed by the government (Law Number 17 of 2003 article (20) concerning State Finance ) The function of the legislative budget deals with the implementation of policies in the form of work programs and development of government that are prepared based on needs and endorsed as binding legal products, as well as a measure that shows the DPRD's partiality towards the people (Asshiddiqie, 2011).

The above description was justified by informants, especially from the Head of the Budget Division and the Head of Bappeda, that the high level of difficulty was at the time of the preparation of the budget plan which had to accommodate all interests both development, routine expenditure with regional revenues or revenues.

Because after being submitted to the legislature and studied, the next step is for the legislature to conduct a working meeting with the relevant Dinas in accordance with the respective fields of the existing commission.

In East Java, the preparation of budget proposals or the draft APBD by executives is based on the General Budget Policy (KUA) and strategies and priorities (SP) derived from regional strategic plans (Renstrada). KUA and SP are stated in a memorandum of understanding between the executive and the legislature. In the formulation stage there is relatively no conflict between the executive and the legislature, while at the next stage, namely when the draft budget is proposed to be a set budget, it usually must go through debate and negotiation between the two parties.

b. Supervision of Budget Use

a. Benchmarks for success

The measure of success according to some informants related to the first budgeting is that from the aspect of acceptance it can meet the target and even expected to exceed the set targets, and the second from the aspect of expenditure or budget absorption carried out by the OPD can meet the targets and targets mission.

From the results of the achievement of the mission of the East Java provincial government, it can be as in the table below: 


\begin{tabular}{|l|l|c|c|c|}
\hline NO & INDIKATOR & TAHUN & TARGET & CAPAIAN \\
\hline 1 & Human Development indexs & 2014 & $73,15-73,45$ & 68,14 \\
\hline & & 2015 & $73,46-73,76$ & 68,95 \\
\hline & & 2016 & $73,77-74,07$ & \\
\hline 2 & Gender Development indexs & 2014 & $67,18-67,78$ & 90,83 \\
\hline & & 2015 & $67,78-68,39$ & 91,07 \\
\hline & & 2016 & $68,40-69,00$ & 91,91 \\
\hline 3 & Open unemployment rate & 2014 & $4,32-4,23$ & 4,19 \\
\hline & & 2015 & $4,22-4,13$ & 4,47 \\
\hline & & 2016 & $4,12-4,03$ & 4,21 \\
\hline 4 & Indkes GINI & 2014 & $0,363-0,360$ & 0,37 \\
\hline & & 2015 & $0,359-0,356$ & 0,40 \\
\hline & & 2016 & $0,355-0,352$ & 0,40 \\
\hline 5 & income distribution & 2014 & $20,41-20,75$ & 18,63 \\
\hline & & 2015 & $20,76-20,89$ & 18,77 \\
\hline & & 2016 & $20,90-20,95$ & 19,00 \\
\hline
\end{tabular}

From the data, it can be seen that there is still much that must be done by the government, related to budgeting issues, and one of them is the problem of effectiveness and performance that must always get attention.

Assessment of the effectiveness of P2KP program fund management will be measured using the concept of goal optimization, which is to see the extent to which the goals or objectives of the P2KP program can be achieved.

Based on the opinions above, it can be concluded that productivity is a comparison between outputs and inputs and expresses how to use resources in producing goods and services.

The performance evaluation indicators other than those described above are capital growth. Working capital is one of the most important assets in the company. Because without working capital the company cannot fulfill the funding needs to carry out its activities. The working capital turnover period, that is, since cash is invested in the elements of working capital to become cash again, is less than one year or short term. This working capital turnover period shows the level of efficiency of the use of working capital.

BKM capital growth can be seen through the increase or decrease in capital from the profit or loss obtained by each of these organizations. Profit occurs when the income earned in a period is greater than the costs incurred, otherwise the loss will arise if the income is lower than the costs incurred (Sutrisno, 2001: 12).

1.6. Central Development Planning and regional synergy in the RKP

In the implementation of development, which is elaborated through adequate budgeting, the Provincial Government must also align with the planning carried out at the center, therefore the synergy of Central and Regional Development planning in the RKP can be described as follows:

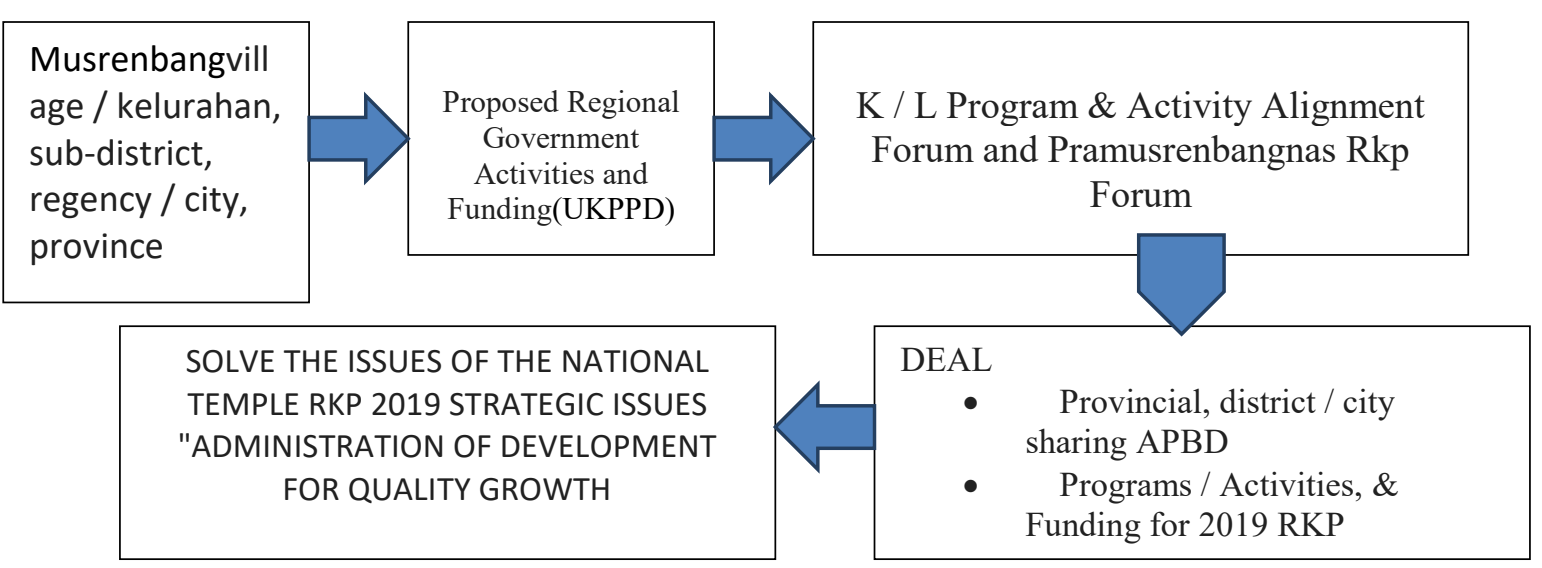

\section{Budgeting mechanism}

The initial draft of the RKP included development priorities, the design of a macroeconomic framework and funding, indications of the Ministry / Institution (K / L) program, cross K / L programs and cross-regional 
programs, as well as the implementation rules. The $\mathrm{K} / \mathrm{L}$ composes the Ministries / Institutions Work Plan (Renja K / L) as an ingredient to improve the preliminary draft 2018 RKP. To improve the preliminary draft 2018 RKP, a 2017 Musrenbang Series is held to realize the RKP synergy with the Regional Government Work Plan (RKPD) in the framework of achieving national development priority targets. To support the smooth preparation of this $2018 \mathrm{RKP}$,

Through the implementation of the East Java Province Musrenbang RKPD in 2019 it is hoped that participatory programs / activities can be formulated and in line with National development priorities, in accordance with the Law that the implementation of regional government is directed at accelerating the realization of community welfare through increasing and equalizing community income, employment opportunities, employment strive, improve access and quality of public services and regional competitiveness.

As a form of correlation between the substance of the RKPD and the funding framework in the RKPD, the support for participation of community resources and other funding sources is an important element that must be sought to support development funding, in addition to funding sourced from the APBN and APBD of East Java Province.

But in the implementation in the field it turned out to be different, Musrenbang Musrenbang which is expected to absorb aspirations from the bottom as well as a combination of top down and bottom up, because the time available is too short, so it seems that the implementation is only a confirmation of what planned.

Coordination of the executive budget team

The implementation of the program synchronization process and funding through the Provincial Musrenbang is expected to build a budget planning structure that is able to realize the solution to the problems faced by East Java.

Coordination of the Budget Team chaired by the Regional Secretary In the management of regional finance, the regional budget for income and expenditure is the basis of Regional financial management within 1 (one) budget year in accordance with the law concerningstate finances. The Regional Budget illustrates the regional fiscal needs in administering Government Affairs that are under the authority of the Region, both Obligatory Affairs related to Basic Services and not related to Basic Services or Selected Affairs, as referred to in Article 11 paragraph (1) of Law Number 23 Year 2014 concerning Regional Government.

The preparation of the Regional Budget is intended to provide a basis for the use of regional finance by prioritizing transparency and accountability and being accountable. Therefore, coordination becomes something very important for achieving one language and one perception for all stakeholders.

Priority scale determination

Priority scaling is always associated with the vision and mission that the East Java Provincial Government wants to achieve, but the findings of the research that has been carried out also show that there are several missions that are not supported by adequate budgeting, for example in the education sector, after high school and school Special Intermediate delegation of authority to the Province, not necessarily the Province can finance all the education needs of SLA and SMK levels in East Java, on the other hand some authorities that were previously provincial authorities have been taken over by the central government, such as weigh bridges, class A terminals , and this will result in a decrease in local revenue.

To overcome the decrease in income, according to the interviews that have been conducted, the provincial government made a breakthrough in the form of innovation, one of which is to provide fines for the transfer of names and Motor Vehicle Registration, because there are still many residents who have motorized vehicles with outside license plates provinces and letters of motorized vehicles that have expired but are not renewed.

Coordination with the legislative budget team

An interesting finding in terms of coordination with the Legislative Budget Team was that after drafting an executive budget and submitting it to the People's Representative Council, especially those in the Board of Budget, there was a long discussion regarding the composition of the budget and not even the possibility of transactional budgeting between executives and legislative, in an executive sense it will accommodate the wishes of board members.

Supervision of budget use

Basically supervision is fully directed to avoid the possibility of fraud or deviation from the objectives to be achieved. through supervision it is expected to help implement the policies that have been set to achieve the goals that have been planned effectively and efficiently. In fact, through supervision created an activity that is closely related to the determination or evaluation of the extent to which the implementation of work has been carried out. Supervision can also detect the extent to which a leader's policies are carried out and the extent to which deviations occur in the implementation of the work.

Supervision of budget use is carried out in two aspects, namely internal supervision carried out by the 
Inspectorate, which focuses more on avoiding initial deviations and it is hoped that the use of the budget will not deviate from what was planned. On the other hand supervision is also carried out by the Supreme Audit Agency but is more of an audit of budget use.

But the results of observations in the field sometimes also see some things that are biased, which in the initial report on the results of the examination, when formulating clarification from budget users, there were still transactions between budget users and supervisory personnel.

\section{Benchmarks for success}

The benchmark for the success of budgeting is inseparable from the performance of the success of Regional Organizations (OPD) or regional government bureaucracies can be measured through the Main Performance Indicators (IKU). This benchmark can be found in three models that are viewed from different angles, namely from the point of view of the function of the distribution of authority (Mendagri), the field of planning functions (Bappenas), the viewpoint of the accountability function (Menpan). As stated by the East Java Provincial Secretary Dr H AkhmadSukardi MM, It was stated that in the model of the authority distribution function there are key indicators that contain various kinds of indicators of mandatory affairs at the policy level and policy implementation levels. Meanwhile, the planning function model and accountability function model often intersect in implementing in the local government environment. For example, in the regions there are two different implementation provisions but the product has the same substance. In this case, the strategic plan version of Bappenas with the Menpan version, as well as the derivation between the Bappenas version of the work plan and the annual performance version of the Menpan. In fact, he continued, the main performance indicators for the Menpan version were only beginning to be discussed at the end of 2008. While the main performance indicators of the Bappenas version had been raised in the new RPJMD in early 2009. He further said, IKU was designed with the aim of measuring the success of goals, the target, or the outcome of the tasks and functions of each echelon I and II OPD, is good atprovincial government environment as well as the district / city government. Previously, the ministry of state utilization of the state apparatus had issued a manual for the preparation of the IKU, but the instructions in reality still could not be optimally operated so that the East Java Provincial Government needed to provide operational understanding through this Bintek.

\section{Increased PAD}

Based on the data from the Provincial Government Statistics Agency (BPS), the realization of East Java Provincial Government (Pemprov) budget revenues reached Rp. 26.53 trillion. The amount consists of Regional Original Income (PAD) worth Rp. 15, 82 trillion, balancing funds Rp. 9.04 trillion, others legitimate regional revenues Rp. 105 billion, and regional funding Rp. 1.57 trillion. Still according to BPS data, East Java Provincial Government PAD value experienced an upward trend throughout the period 2013-2016. However, in the Regional Budget (APBD) 2017 the provincial PAD with thousands of cities in Surabaya is only targeted at Rp. 14.9 trillion or $5.8 \%$ lower than the previous year. East Java's economy is based on Gross Regional Domestic Product (GRDP ) on the basis of prices valid until the third quarter of 2017 reaching Rp. 1,498 trillion. While GDP at constant prices accumulated in quarter I-III 2017 grew 5.21\% from the same period the previous year.

(Read Databoks: The Highest Level of Ease of Business in East Java)

$$
\text { Pendapatan Asli Daerah Pemprov Jawa Timur (2013-2017) }
$$

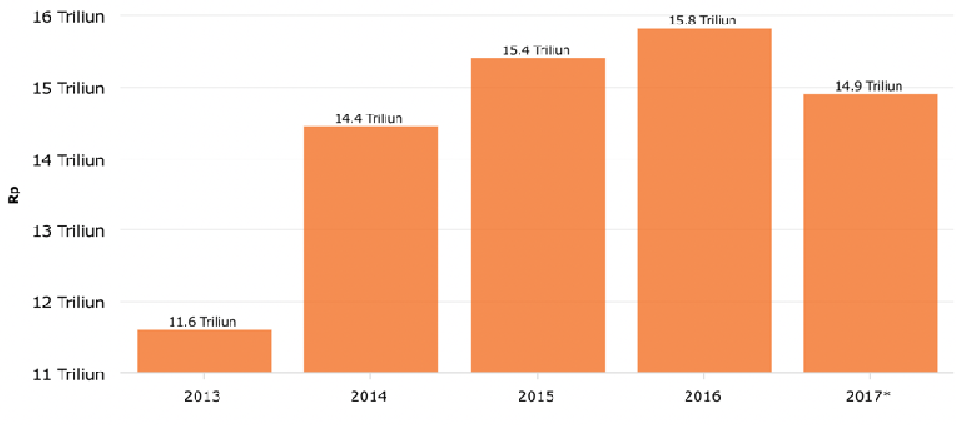

Implications for public policy

Analysis of Public Policy and Analysts Analysis of public policy has a designative goal with an empirical approach (based on facts), is an evaluation with an evaluative approach and is recommended by a normative approach. The analysis procedure is based on the location of time in relation to the action divided by two, namely ex anteand ex post. Predictions and recommendations are used before actions are taken or for the future (ex ante), while descriptions and evaluations are used after the action occurs or from the past (ex post). Ex post 
analysis relates to retrospective policy analysis commonly carried out by social and political experts, while ex ante analysis relates to prospective policy analysis commonly carried out by economists, systems analysis and operations research. Policy analysis usually consists of problem formulation, coverage, forecasting, evaluation, recommendations and conclusions. A policy analyst is someone who conducts policy analysis

In relation to the policy implications as mentioned above, the Musrenbang can actually be a more concrete answer because the objectives of the Musrenbang itself are:

1. Agree on Regional development issues;

2. Agree on Regional development priorities;

3. Agree on the direction of development policy for the district / city in the province;

4. Agree on programs, activities, indicative ceilings, performance indicators and targets and locations;

5. Alignment of Regional development programs and activities with National development goals and priorities; and

6. Clarification of programs and activities that are provincial authorities with the proposed district / city programs and activities based on the results of the district / city Musrenbang.

Model of public policy in budgeting

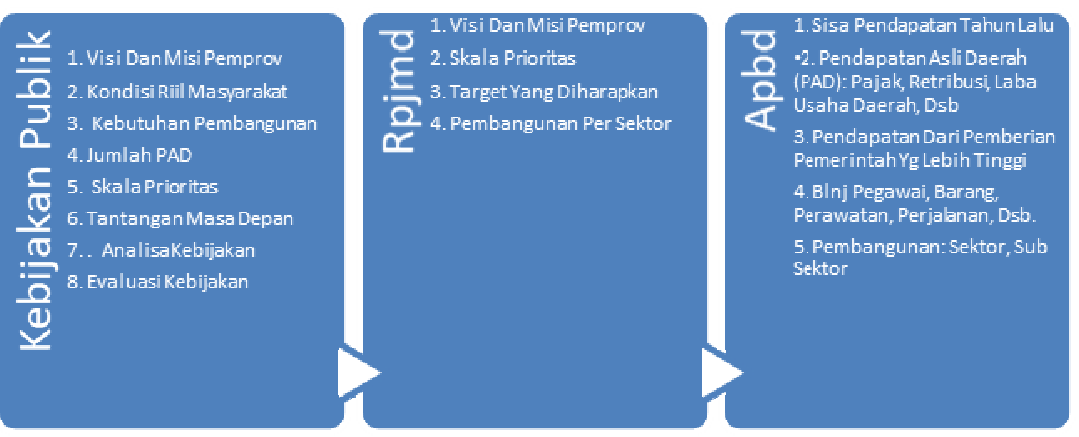

From the description above, the model of public policy implemented by the East Java Provincial Government can be described as follows:

Tabel 3

TARGET AND REALIZATION OFAPBD 2014-2018

\begin{tabular}{|c|c|c|c|c|c|c|c|c|c|c|c|c|c|c|}
\hline \multicolumn{3}{|c|}{2014} & \multicolumn{3}{c|}{2015} & \multicolumn{3}{c|}{2016} & \multicolumn{3}{|c|}{2017} & \multicolumn{3}{|c|}{2018} \\
\hline $\mathrm{T}$ & $\mathrm{R}$ & $\%$ & $\mathrm{~T}$ & $\mathrm{R}$ & $\%$ & $\mathrm{~T}$ & $\mathrm{R}$ & $\%$ & $\mathrm{~T}$ & $\mathrm{R}$ & $\%$ & $\mathrm{~T}$ & $\mathrm{R}$ & $\%$ \\
\hline 20,96 & 20,01 & 95,46 & 24,36 & 22,95 & 94,19 & 24,62 & 23,86 & 96,93 & 30,94 & 28,89 & 93,39 & 30,76 & 28.33 & 92,33 \\
\hline
\end{tabular}

Information : In units of trillion, processed by researchers

The failure to set targets has been set because one of the causes is the auction value which is sometimes under the budget plan. But the range between $94 \%$ and $95 \%$ is considered good compared with other provinces. Public Expenditure Ratio to GRDP

Tabel 4

APBN reality

\begin{tabular}{|c|c|c|}
\hline \multicolumn{3}{|c|}{ APBN (Realization) } \\
\hline no & Description & Total \\
\hline 1 & $\begin{array}{l}\text { Deconcentration Fund } \\
\text { (Dekon) }\end{array}$ & 423.768 .773 .386 \\
\hline 2 & Co-Administration & 32.518 .675 .967 .792 \\
\hline 3 & $\begin{array}{l}\text { Regional Office } \\
\text { (KD/VerrticalInstancy) }\end{array}$ & 7.396 .819 .682 .938 \\
\hline 4 & $\begin{array}{l}\text { Headquarters } \\
\text { (Headquarters in Region) }\end{array}$ & 1.110 .539 .019 .682 \\
\hline \multirow[t]{2}{*}{5} & Joint Affairs & 13.283 .609 .100 \\
\hline & TOTAL & 41.478 .087 .052 .898 \\
\hline \multicolumn{3}{|c|}{ APBD (Realization) } \\
\hline no & Description & Total \\
\hline & Regional Expenditures & $28.885 .463 .331 .497,29$ \\
\hline
\end{tabular}

Data :Bappedaprov, processed by researcher,

From Tables 6.1 and 6.2, it can be seen that the preparation of the Regional Budget has been attempted to approach the 2014-2019 RPJMD, even though the realization target is still not optimal.

In order to achieve maximum results of use, public policy in relation to the budget, the strategic issues and 
solutions that can be identified are as follows:

\begin{tabular}{|c|c|}
\hline Strategic Issue & Settlement efforts \\
\hline $\begin{array}{l}\text { The quality of secondary education is not } \\
\text { optimal, the quality of services and the provision } \\
\text { of health infrastructure, labor productivity, and } \\
\text { poverty reduction. } \\
\text { The lack of land, sea and air connectivity to } \\
\text { support economic development. } \\
\text { Low food productivity, added value of } \\
\text { 3. agriculture, plantations, livestock and fisheries and } \\
\text { not optimal tourism management. } \\
\text { Not yet optimal management of energy and } \\
\text { mineral resources, water resources and } \\
\text { preservation of natural resources. } \\
\text { Prone to peace and order and abuse of drugs } \\
\text { and drugs. }\end{array}$ & $\begin{array}{l}\text { 1. Speed up compliance with standardsminimum } \\
\text { service in order to improve accessibility and } \\
\text { quality of education and healt } \\
\text { 2. Improve labor quality and productivity as well as } \\
\text { poverty reduction. } \\
\text { 3. Developing and infrastructure to accelerate the } \\
\text { development of reducing inequality between } \\
\text { regions. } \\
\text { 4. Increasing Productivity and Quality of agricultural } \\
\text { products, industry and tourism. } \\
\text { 5. Improve energy security and resource governance. } \\
\text { 6. Increasing peace and order towards potential } \\
\text { conflict issues }\end{array}$ \\
\hline
\end{tabular}

\section{Conclusion}

From the description above, which is titled an analysis of public policy on the preparation of the expenditure budget and income of the East Java province (the 2014-2019 East Java provincial RPJMD study and its impact on the regional budget), and in accordance with the results of the study, it can be concluded that:

a. In general, public policies carried out by the East Java provincial government related to the preparation of regional budget and income in general have led to positive things.

b. But even so it does not mean that the good thing is when it is linked to the policy analysis study, it turns out there are still some weaknesses that must be improved, especially in the concept of development plan deliberation which takes less time, so the results produced in musrenbang seem less optimal .

c. The operationalization of the Government's vision and mission needs to be elaborated and disseminated to the lowest ranks, giving rise to the unity of the Language and the steps of all stakeholders.

d. Based on the results of observations conducted the researchers found that the quality of existing human resources, especially those related to budgeting, still needed to get attention.

e. On the other hand there are also obstacles where the transfer or retirement of an employee is normal, but even so in the selection of an employee's placement must also be based on truly one's competence and integrity.

f. One of the problems in the cycle of public policy making which is very crucial is to leverage the causes of problems, which are sometimes intervened with political interests, which tend to occur in transactional politics in budgeting, especially between the Regional Budgeting Team and the Regional House of Representatives Budget Board.

g. Besides that another problem that was also found was the absence of tools in the framework of policy monitoring and evaluation, so that in the preparation of the budget there would be known points of weakness that needed to be addressed and points that must be maintained.

\section{References}

Adinda Permatasari Rahadian, Analisis Implementasi Kebijakan Tentang Keterbukaan Informasi Public Studi Kasus Pada Kementerian Pertanian, Jurnal Dialog Kebijakan Public Vol 3 Tahun 2009

Anderson, James E. 1997, Publik Policy Making, New York : Holt Reinhart and Winston

Anderson, Jonathan, F, 2006, The Rhetorical Impact of Evil on Publik PolicyAdministration \& Society; Jan 2006; 37, 6; ABI/INFORM Global ,pg. 719

Blau, Peter M, and Meyer, Marshall, 2000, Birokrasi Dalam Masyarakat Modern, Prestasi Pustaka Raya, Jakarta

Caiden,G.E. 1991, Administrative Reform Comes of Age, New York, N.Y: de Gruyter

Cheris Enjelita Kaunang, Amran T Naukokodan Albert T Londa' Jurusan Ekonomi Pembangunan, Fakultas Ekonomi dan Bisnis Universitas Sam Ratulangi, Manado

David Efendi danSri WuryantiAnalisis perkembangan kemampuan keuangan daerah dalam mendukung pelaksanaan otoda di kabupaten nganjuk Fakultas Ekonomi, Universitas Muhammadiyah Ponorogo

Dessy Angelia, Rosita SuryaningsihThe Effect of Environmental Performance And Corporate Social Responsibility Disclosure Towards Financial Performance (Case Study to Manufacture, Infrastructure, And Service Companies That Listed At Indonesia Stock Exchange)

Diah Hariani, analisa kebijakan pelayanan publik di kabupaten gianyar Penyelenggaraan pelayanan public oleh 
lembaga pemerintah kepada masyarakat warga negara

Dharma, Surya, 2005, Manajemen Kinerja, Falsafah teori dan penerapannya, Jogyakarta, Pustaka pelajar

Dunn, William N, 2000, Pengantar Analisis Kebijakan Publik, edisi kedua, Jogyakarta, Gadjah Mada University Press

Dye, Thomas R. 1988, Politics in state and communities. New Jersey: Prentice Hall

Eade, D.,1998, Capacity Building: An Approach to People-Centered Development, Oxford, UK: Oxfam,GB

Easton, D. (1965). A Systems Analysis of Political Life. New York/London: John Wiley.

Edralin, J.S., 1998, The New Lokal Governance and Capacity Building: A Strategic Approach Regional. Development Studies, Vol. 3

Ferdinand Kerebungu, Pelayanan Birokrasi dalam otonomi daerah, jurnal dialog kebijakan public vol 8 tahun 2010

Fredickson, George, 1997, The Spirit of Publik Administration, San Fransisco: Jossey Bass

Fiszbein, A, 1997, The Emergence of Lokal Capacity: Lesson from Columbia World Development, Vol. 25(7) hal $1029-1043$

Friedmann, John, 1992, Empowerment: The Politics Alternative Development, Cambridge, Blackwell

Grindle,M.S. (editor), 1997, Getting Good Government: Capacity Building in the Publik Sector of Developing Countries, Boston, MA: Harvard Institute for International Development

HeriSusanto, Jurnal Organisasi dan Manajemen, Volume 10, Nomor 1, Maret 2014

Ijones, Charles O, 1984, An Introduction to the Study of Publik Policy, Theird Edition Books/Cole Publishing Company, California

Islamy, M. Irfan, 1998, Prinsip-prinsip Perumusan Kebijaksanaan Negara, Bumi Aksara Jakarta

2001, Agenda Kebijaksanaan Reformasi Administrasi Negara, Pidato Pengukuhan gelar Guru Besar: Jurnal Administrasi Negara, Vol.II no. 1 Malang

Kenis, P., and Schneider, V. (1991). Policy Networks and Policy Analysis: Scrutinizing a New Analytical Toolbox. In B. Marin and R. Mayntz (eds), Policy Networks. Empirical Evidence and Theoretical Considerations, pp. 25-62. Boulder/Colorado, Frankfurt: Campus Verlag/Westview Press.

Jurnl Keuda Vol. 2 No. 3 ISSN 2477-7838

JIAKP, Vol. 4, No. 1, Januari 2007

Coryanata, I. (2012). Akuntabilitas, Partisipasi Masyarakat dan Transparansi Kebijakan Publik sebagai Pemoderasi Hubungan Pengetahuan Dewan Tentang Anggaran dan Pengawasan Keuangan Daerah. Jurnal Akuntansi dan Investasi,12(2), 110-125.

Retrieved from http://journal.umy.ac.id/index.php/ai/article/view/678/83

Hill, Lary B, (1992) The State of Public Bureaucracy, ME Sharpe, Inc, Armon, New York

Hughes, Owen E., (1994) Public Management and Administration, St. Martin's Press, London

Kousoulas, D. George, 1979, On Government and Politics. Massachusetts: Duxbury Press

Kreitner, Robert, 2005, Perilaku Organisasi buku 1, Salemba empat, Jakarta , Perilaku Organisasi, buku 2, Salemba Empat, Jakarta

Maryono, Y. Warella, Kismartini, implementasi kebijakan pengelolaan keuangan daerah propinsi Jawa Tengah

Muhadam Labolo, Reformasi Birokrasi dan implementasi Good Governance.jurnal Reformasibirokrasi

Namira Osrinda ; Arman Delis, Analisis Konsistensi Perencanaan dan Penganggaran serta Implikasinya terhadap Capaian Target Kinerja pada Badan Perencanaan Pembangunan Daerah Kabupaten Merangin

Nugroho, Riant, 2008, Publik Policy, Jakarta, PT. Elex Media Komputindo

Nurhayati , Program Studi Ilmu Pemerintahan Fakultas Ilmu Sosial dan Ilmu Politik Universitas Kepulauan Riau, Batam Indonesia Analisis Teori Transparansi Pengelolaan Keuangan Daerah di Indonesia

Nur Afiyah Maizunati, Analisis Kondisi Keuangan Pemerintah Daerah Kota Magelang Dalam Klaster Kota Di Jawa-Bali

Parson, Wayne, 2006, Publik Policy, Pengantar Teori dan Praktik Analisis kebijakan, Jakarta, Kencana media

Prayudi Nugroho, Pusdiklat Pengembangan SDM, Pengajar pada PKN STAN

R. Agoes Kamaroellah, 2017. Analisis Kinerja Pengelolaan Anggara Pendapatan dan Belanja Daerah Pada Badan Keuangan Daerah Kabupaten. Pamekasan. Laporan Penelitian Madya Sekolah Tinggi Agama Islam Negeri Pamekasan, Nuansa, Vol. 14 No. 1 Januari - Juni 2017

Robbins Stephen, P, 2003, Perilaku Organisasi edisi kesepuluh, Jakarta Indeks

Silalahi, Grabiela Amin, 2003, Metodologi Penelitian dan Studi Kasus, Sidoarjo, Citra Media

Riege, Andreas and Lindsay, Nicholas, Knowledge management in the publik sector: stakeholder partnerships in the publik policy development, Journal of Knowledge Management, VOL. 10 NO. 3 2006, pp. 24-39, Q Emerald Group Publishing Limited, ISSN 1367-3270

Smith,B.C.,1985, Decentralization The Territorial Dimension of the State. London: George Allen \& Unwin

Sultan M. Kebijakan Pengelolaan Keuangan DaerahDan Akuntabilitas Penggunaan Anggaran,dalamJURNAL ACADEMICA Fisip Untad VOL.06 No. 01 Februari 2014 
Vincent, Andrew, 2007, German Philosophy and British Publik Policy: Richard Burdon Haldane in Theory...Journal of the History of Ideas; Jan 2007; 68, 1; Academic Research Librarypg. 157

Wahab, Solichin Abdul, 2002, Analisis Kebijakan dan Formulasi ke implementasi Kebijaksanaan negara, Jakarta, Bumi Aksara

Weitzer, Beth C; Silver,Diana ,2006, Efforts to Improve Publik Policy and Programs through Data Practice: Experiences in 15 Disterssed American Cities, Caitlyn Brazill,Publik Administration Review; May/Jun 2006; 66, 3; ABI/INFORM Globalpg. 386

Wibawa, Samudra, dkk, 1994, Evaluasi Kebijakan Publik, Yogyakarta, Gadjahmada University Press

Wibowo, 2007, Manajemen Kinerja, Jakarta, PT. Raja Grafindo Persada

Winarno, Budi, 2007, Kebijakan Publik Teori \& Proses, Yogyakarta, Media Pressindo

wirmie eka putra coriyatiDosen Fakultas Ekonomi dan Bisnis Universitas Jambi 